\title{
ステント留置、ジェット換気による肺再膨張直後の肺水腫, 多発塞栓症
}

河野 靖生 山田 信一 加納 龍彦

\begin{abstract}
要約: 肺癌により左主気管支狭窄, 左完全無気肺を来している患者に対しDumon 式気管内ステ ント挿入術を施行した。ステントを留置し, 高頻度ジェット換気 (high frequency jet ventilation, HFJV）により左肺を膨張させた直後血圧低下, 低酸素血症, 心電図 II誘導でST 上昇, 完 全房室ブロックを生じ, 脳梗塞を合併した。その原因として, 再膨張性肺水腫に加えて, 肺動 静脈内に停滞していた血栓, 腫瘍片の飛散により広範な塞栓症を同時に生じた可能性が考えら れた。長期に虚脱した肺を HFJVにより急激に再膨張させるときには肺水腫のみならず多発塞 栓症に対する注意が必要と考えられる。
\end{abstract}

Key words: (1) high frequency jet ventilation, (2) circulatory collapse, (3) re-expansion pulmonary edema

\section{はじめに}

肺・縦隔病変に起因した気管・気管支狭窄に対し, 低 侵襲で呼吸機能を改善し, QOLの向上をもたらすステ ント挿入術は，一般的な治療として普及してきた。な かでも硬性気管支鏡を用いた Dumon 式ステントの気 管支内挿入術が普及している。

今回, 肺腫瘍 (腺癌) により左気管支狭窄, 左肺完 全虚脱を来している患者に対して, Dumon式気管支内 ステントを留置した後，高頻度ジェット換気（high frequency jet ventilation, HFJV) により左肺を膨張さ せたところ，肺水腫のみならず心電図 II 誘導で ST の 上昇，血圧低下，低酸素血症，続いて完全房室ブロッ ク, 脳梗塞など多発塞栓症状を生じた症例を経験した ので報告する。

\section{症例}

患者は 60 歳, 男性（身長 $168 \mathrm{~cm}$, 体重 $59 \mathrm{~kg}$ )。39 年にわたる 20 本・ $\mathrm{day}^{-1}$ の喫煙歴と喘息の既往があっ た。 1 年 6 カ月前から腰痛を訴えていたが, 5 カ月経過 し下肢にしびれも出現した。原因究明のために全身の
精査を進めたところ, 原発性左肺腺癌と診断され, 脳 転移，骨転移（腰椎，仙骨）も発見された。原発巣な らびに転移巣に対し放射線治療を行い，その後通院で 経過を観察していたが，咳がひどくなり呼吸困難を訴 えるようになった。精査の結果, 原発の左側肺癌が増 大し, 左主気管支を外側から圧迫あるいは内側への浸 潤による気管支狭窄を生じ，左側肺は完全に虚脱して いた。胸水貯留が認められたため再度入院し, 左側胸 腔内にドレナージカテーテルを留置し胸水の持続吸引 が始められた。その後も, 依然として左肺は虚脱した ままであった。入院3週間後にDumon式ステントの左 主気管支内挿入が予定された。気管支ファイバースコ ピー（bronchofiberscopy, BFS）ではピンホール状に 狭窄した左主気管支が確認された。術前の自発呼吸下 動脈血ガス分析值（room air）は $\mathrm{pH} 7.41, \mathrm{PaO}_{2} 73$ mmHg, $\mathrm{PaCO}_{2} 36 \mathrm{mmHg}, \mathrm{HCO}_{3}{ }^{-} 22.8 \mathrm{mmol} \cdot l^{-1}, \mathrm{BE}$ $-1.2 \mathrm{mmol} \cdot l^{-1}$ であった。

手術室入室 30 分前に麻酔前投薬として, 硫酸アトロ ピン $0.3 \mathrm{mg}$, 塩酸ヒドロキシジン $25 \mathrm{mg}$ を筋注した。 ミダゾラム $7 \mathrm{mg}$, クエン酸フェンタニル $100 \mu \mathrm{g}$ 静注 で麻酔を導入し, 臭化ベクロニウム $6 \mathrm{mg}$ 静注で筋弛 
緩を得た後に 100\%酸素で換気を行い硬性鏡を気管に 扱入した。呼吸管理は硬性鏡側孔に麻酔器の呼吸回路を 接続し酸素一合成空気の混合ガスを用いた間欠的陽圧換 気で行った。硬性鏡と気管の間のガスリークに対しては ガーゼパッキングで対処した。麻酔はプロポフォールの 持続静注で維持した。問題なくDumon式ステントは左 主気管支狭窄部に留置されたが，ステント抑入後も用 手陽圧換気に対して左肺の膨らみが認められなかった。 BFSを行うとステント留置末梢側の左側気管支内腔を 閉塞する腫瘤が認められた。外径 $6 \mathrm{~mm} の 2$ チャネル 付きBFS（BF Type 2 T10, Olympus 社）を介して レーザー焼灼術が予定された。レーザー燒灼術中の垀 吸管理は自発呼吸温你下に行うこととし, 吸人酸素濃 度は $\mathrm{SpO}_{2} 100 \%$ を維持できる最小濃度 $60 \%$ とした。左 側気管支内腫瘤をレーザー焼灼後に陽圧換気を行った が依然として左肺の膨らみがみられなかった。そこ で, 焼灼に用いたBFSの先端を左主気管支に進めBFS の側孔(直径 $1.5 \mathrm{~mm}$ )をジェットベンチレーター(HFO JET Ventilator, 泉工医科工業株式会社) と接続し 100 \%酸素で HFJV（駆動圧 $1 \mathrm{~kg} \cdot \mathrm{cm}^{-2}$, 頻度 $7 \mathrm{~Hz}$, 呼 気吸気時間 (inspiratory-expiratory time, I/E) 比 1:1)を行った。HFJV 開始直後, 持続吸引中（-10 $\left.\mathrm{cmH}_{2} \mathrm{O}\right)$ の左側胸腔ドレーンより約 $500 \mathrm{~m} l$ の渗出液 が流出し, 左肺が膨張されたと考えすぐに HFJVを中 止した。この時, ドレーンからは出血やエアリークは 認められず, 気管からの出血はなかった。ほぼ同時に 血圧低下 (収縮期血圧 $60 \mathrm{mmHg}$ ), 心拍数低下 (40 bpm)，心電図 II 誘導で ST 上昇，自発呼吸の消失と气 れに伴うチアノーゼ, $\mathrm{SpO}_{2}$ の低下 $(89 \%)$ が観察され た。直ちにプロポフォールの投与を中止し, 塩酸エチレ フリン $2 \mathrm{mg}$, 硫酸アトロピン $0.5 \mathrm{mg}$ を静注した。硬 性鏡から通常の内径 $8.5 \mathrm{~mm}$ の低圧, 高容量カフ付シ ングル気管チューブに入れ替え, 右橈骨動脈へカニュ レーションし動脈圧をモニタした。その後, 気管内吸 引をしたが肺水腫に特徴とされる泡涑状の痰はみられ なかった。動脈血ガス分析值 $\left(\mathrm{F}_{\mathrm{IO}} \mathrm{O}_{2} 1.0\right)$ は $\mathrm{pH} 7.395$, $\mathrm{PaO}_{2} 73 \mathrm{mmHg}, \mathrm{PaCO}_{2} 33 \mathrm{mmHg}, \mathrm{HCO}_{3}{ }^{-} 20.0 \mathrm{mmol}$. $l^{-1}, \mathrm{BE}-3.7 \mathrm{mmol} \cdot l^{-1}$ であった。

いったんは血圧と脈拍の増加が得られたが, 続いて 完全房室ブロックを生じ，再び低血圧となった。心拍 数管理のため右内頸静脈よりスワンガンツペーシング ポート（Baxter社製，米国）を挿入した。㨉入中に洞 調律に復するも, その後 $70 \mathrm{mmHg}$ 前後の収縮期血圧 が約 20 分続き, 肺動脈収縮期圧は $50 \mathrm{mmHg}$ 前後を示 していた。血圧低下, 徐脈に対し塩酸ドパミン $5 \mu \mathrm{g}$. $\mathrm{kg}^{-1} \cdot \mathrm{min}^{-1}$, 塩酸ドブタミン $5 \mu \mathrm{g} \cdot \mathrm{kg}^{-1} \cdot \mathrm{min}^{-1}$, 心筋

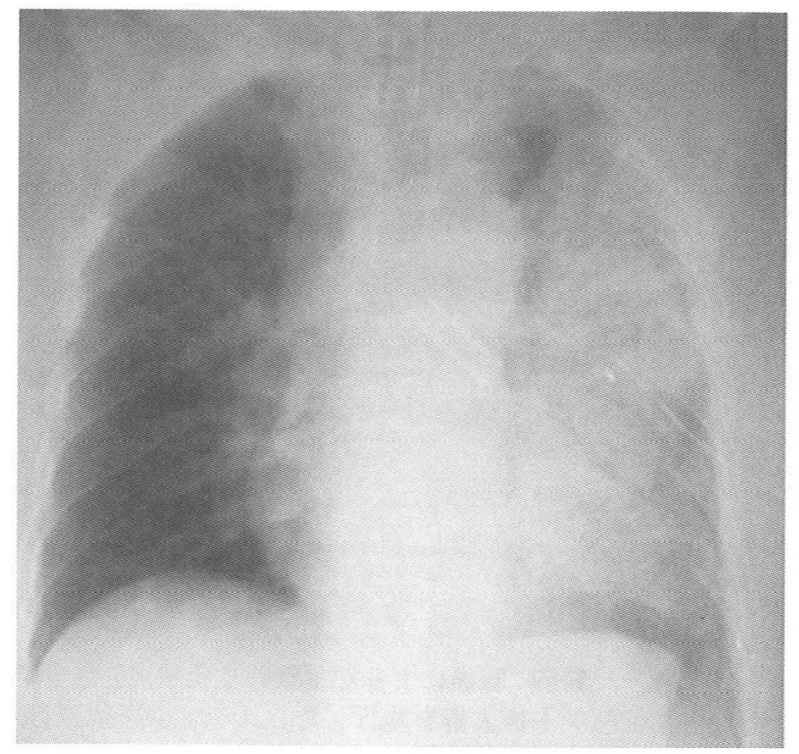

Fig. 1 Chest radiogram after rapid re-expansion of the left lung by jet ventilation.

虚血に対しニトログリセリン $0.5 \sim 1 \mu \mathrm{g} \cdot \mathrm{kg}^{-1} \cdot \mathrm{min}^{-1}$ の 持続投与を開始した。約10分後に収縮期血圧 $80 \mathrm{mmHg}$ 台, 心拍数 $120 \mathrm{bpm}$ となり, 心電図上は洞調律, ST 変 化の回復を認めた。自発呼吸も回復し, 呼吸回数, 換 気量に問題はなかったが, JCS 20〜30であったため, 気管择管したままICUへ入室した。胸部X線写真では 胸水の貯留はほとんどみられなかったが, 左肺は膨張 しているもののスリガラス様に透過性の低下を認めた (Fig. 1)。手術室退室時の $\mathrm{PaO}_{2}$ は2 $239 \mathrm{mmHg}\left(\mathrm{FIO}_{2} 0.8\right)$ であった。

術後は内科 ICUで人工呼吸管理を行い, ミダゾラム 持続静脈内投与により鎮静を保った。人工呼吸器は一 回換気量 $600 \mathrm{ml}$, 同期式間欠的強制換気 (synchronized intermittent mandatory ventilation, SIMV) 15 $\mathrm{min}^{-1}, \mathrm{FIO}_{2}$ 0.9, PEEP $4 \mathrm{cmH}_{2} \mathrm{O}$ に設定し, $\mathrm{pH} 7.38$, $\mathrm{PaO}_{2} 168$ mmHg, $\mathrm{PaCO}_{2} 38 \mathrm{mmHg}$ であり, 酶酸メ チルプレドニゾロン $500 \mathrm{mg}$ を静脈内投与した。塞栓症 の可能性を考え, ヘパリン 15,000 単位· $\mathrm{day}^{-1}$ 持続静注 を開始した。また, 術当日の夜間より 1 〜 分間持続 する一過性の痤攣発作が生じたため，適宜フェニトイ ンナトリウム, ジアゼパム静注を行った。術後 1 日目 の頭部 CT で局所脳梗塞と脳浮腫が認められ, 経胃管 的にイソソルビド (イソバイド ${ }^{\circledR}$ ) $50 \mathrm{ml}$ を投与した。 術直後にHFJVにより膨らんでいた左肺は, 術後 2 日 目には再び含気がなくなり胸水が貯留した。脳波は徐 波を示した。術後 4 日目のCT では右後頭葉の梗塞巣 と脳浮腫の進行が認められた。呼吸状態の回復が認め られないまま肺炎を併発しステント挿入後 7 日目に死 亡した。剖検は施行されなかった。 


\section{考 察}

本症例では, 左肺を再膨張させるためにBFSの先端 を左主気管支に進め側孔から HFJVを試みたところ1， 左肺が急激に再膨張すると同時に重篤な血圧低下，低 酸素症ならびに多発塞栓症の発生を疑う徐脈, ST上 昇, 完全房室ブロック, 自発呼吸消失などを来した。血 圧低下, 低酸素症の原因として, 気管支狭窄による長 期間の肺虚脱により減少していた左肺血管床が左肺再 膨張に伴い急激に増加し, 相対的循環血液量の減少を 引き起こしたことが考えられた。また, 泡沫状の喀痰 は認められなかったが, 胸部 X 線写真上は再膨張に伴 う血管透過性立進による肺水腫 (re-expansion pulmonary edema, REPE)の病態がうかがえた。肺血流の左 肺へのシフトはそれまで肺ガス交換を維持していた右 肺血流の低下を招き換気血流の異常から酸素化障害を 来したと考えられた。

気胸や無気肺などさまざまな原因により虚脱した肺 が胸腔ドレナージや外科的治療後に急激に再膨張する ことで血管透過性が立進し，REPE を発症することは よく知られている2) 5)。今回の症例に関しては，2 週 間近く肺虚脱を呈していたにもかかわらず，術前評価 および術中管理に関して十分な検討が行われなかった 点は反省すべきものであった。

REPEの発症しやすい条件として重症肺虚脱症例, 3 日以上の長期肺虚脱症例 $\left.{ }^{6)} .7\right)$, 若年者 (40歳未満) ${ }^{8)}$, 過 度の陰圧吸引などが挙げられている。Cinnella らは胸 部外傷後 7 日目に血気胸に対して行われた外科的手術 後, 再膨張により急性循環虚脱を伴う REPEを生じた と報告している9)。一方, 再膨張から REPE発症まで は多くが 3 時間以内といわれている10)。Fujinoら 11) は気胸に対する胸腔鏡下手術 (video-assisted thoracic surgery, VATS) 中にHFJVを使用し肺を膨張 させたところ REPE，循環虚脱，心室細動を発症し， また, Iqbal ら ${ }^{12)}$, Yanagitate ら 13)もVATS中のREPE の発症を報告している。

本症例で特筆すべきことは, 心電図 II 誘導で ST が 上昇し, 続いて完全房室ブロックが生じ, 重篤な循環 虚脱状態になったことである。この原因として, 腫瘍 片や血栓による塞栓症発症の可能性が高いと考える。 術後頭部 CT 検査で, 脳梗塞が認められたことからも 塞栓症が推察される。長期間の左肺虚脱により左側の 肺静脈系に停滞していた血栓または腫瘍片が，急激な 肺再膨張に伴う血流の再開と同時に右冠動脈領域や脳 などに塞栓を引き起こした可能性は十分考えられる。 HFJV 施行直後に循環虚脱に陥ったことから, 空気塞
栓の可能性も論じる必要があるが, 胸腔ドレーンから 血液やエアリークが認められなかったこと, また気道 出血がなかったことから否定的である。

REPEの治療として，軽症の場合は酸素投与と循環 血漿量の維持により対処できるが，本症のような重症 症例では心血管作動薬，ステロイド，利尿薬の投与, PEEP を加えた人工呼吸管理が必要となる2),4),6),12)。手 術の適応がなく中枢気道狭窄を示す肺癌治療法の 1 つ としてステント挿入術を受ける症例では術前より呼吸 状態が悪化しており，ほとんどの場合は緊急手術とし て行われる。急激な肺の膨張を避けることや，塞栓症 を引き起こす可能性があることを予測した抗凝固療法, 頸動脈一時圧迫などの周術期管理が必要と考えられた。 今回我々は，左主気管支狭窄による左肺完全虚脱に 対しDumon式気管ステントを挿入し, HFJVで再膨張 した直後に重篤な低血圧，徐脈，不整脈および低酸素 血症を来した症例を経験した。REPEに加えて多発塞 栓症の合併症が考えられ，十分な注意が必要と思われ た。

\section{文献}

1) 榊 嗣朗, 三島康典, 津田英照, 加納龍彦. 2 チャンネル気 管支ファイバースコープを用いたジェット換気下での小児 異物摘出. 臨床麻酔 1998; 22: 1721-3.

2) 山本 滋, 門倉光隆, 片岡大輔, 他. 自然気胸のドレナージ 後に発症した再膨張性肺水腫（REPE）の 1 症例. 臨床呼吸 生理 2000; 32: 93-5.

3) 河野光智, 澤藤 誠, 小林紘一, 他. 外科的治療後に発症し た再膨張性肺水腫症例. 臨床呼吸生理 2000; 32: 97-9.

4) Milne B, Spence D, Lynn RB, et al. Unilateral re-expansion pulmonary edema during emergence from general anesthesia. Anesthesiology 1983; 59: 244-5.

5) Desiderio DP, Meister M, Robert M, et al. Intraoperative re-expansion pulmonary edema. Anesthesiology 1987; 67: 821-3.

6) 間瀬武則, 加藤真司, 青山貴彦, 他. 胸水吸引排液直後に限 局性再膨張性肺水腫を来した1例. 呼吸と循環 1995; 43: 8158.

7) 小延俊文, 斎藤幸人, 梅本真三夫, 他. 自然血気胸術直後に 再膨張性肺水腫を発症した 1 例. 胸部外科 1997; 50: 796-9.

8) 澤藤 誠, 河野光智, 小林紘一. 再膨張性肺水腫. 呼吸 1998; 17: $740-4$.

9) Cinnella G, Dambrosio M, Brienza N, et al. Reexpansion pulmonary edema with acute hypovolemia. Intensive Care Med 1998; 24: 1117-21.

10) Matuura $Y$, Nomimura T, Murakami H, et al. Clinical analysis of reexpansion pulmonary edema. Chest 1991; 100: 1562-6.

11) Fujino $S$, Tezuka N, Inoue $S$, et al. Reexpansion pulmonary edema due to high-frequency jet ventilation. Report of a Case Surg Today 2000; 30: 1110-1.

12) Iqbal M, Mults AS, Rossoff LJ, et al. Reexpansion pulmonary edema after VATS successfully treated with continuous positive airway pressure. Ann Thorac Surg 2000; 70: 669-71.

13) Yanagitate F, Dohi S, Hayama $Y$, et al. Reexpansion pulmonary edema after thoracoscopic mediastinal tumor resection. Anesth Analg 2001; 92: 1416-7. 


\title{
Abstract
}

Pulmonary edema and multiembolism occurring immediately after pulmonary re-expansion by stenting and jet ventilation in a patient with left lung collapse

\author{
Yasuo Kono, Shinichi Yamada, Tatsuhiko Kano \\ Department of Anesthesiology, Kurume University School of Medicine \\ 67 Asahi-machi Kurume-city Fukuoka 830-0011, Japan
}

\begin{abstract}
A Dumon-type bronchial stent was placed in a lung cancer patient presenting left lung collapse due to stenosis of the left main bronchus. High frequency jet ventilation was then applied to the left lung through a channel of a bronchofiberscope introduced in the left main bronchus proximal to the stent. Immediately after re-expansion of the left lung, circulatory collapse including severe hypotension, bradycardia and hypoxia developed. Considering that abrupt ST elevation and complete A-V block on ECG monitor and cerebral infarction on later CT examination were also accompanied with the event, multiple emboli was suspected as one of the causes of circulatory collapse in addition to re-expansion pulmonary edema. It was presumable that thrombi or tumor breakdowns existed in the left pulmonary vessel might have entered in the systemic circulation following re-expansion and might have been transported to the heart and brain. We should be aware of developing not only re-expansion pulmonary edema but also multiembolism after rapid re-expansion of the lung by jet ventilation in a patient with long term collapse of the lung.
\end{abstract}

Key words: (1) high frequency jet ventilation, (2) circulatory collapse, (3) re-expansion pulmonary edema

J Jpn Soc Intensive Care Med 2004; 11: $27 \sim 30$ 